\title{
Improving Biodegradation of Rice Straw Using Alkaline and Aspergillus niger Pretreatment for Methane Production by Anaerobic Co-Digestion
}

Chin-Hang Shu*, Rajan Jaiswal and Jhih-Syong Shih

Department of Chemical and Materials Engineering, National Central University, Taiwan, Republic of China

\begin{abstract}
Rice straw, an agricultural waste, is readily available as a potential feedstock for the production of fermentable sugars. However, the recalcitrant nature of the lignin during digestion has been the major hindrances for the feasibility of the anaerobic process. At the same time, conversion of animal manure to value added product like biofuels is an important breakthrough for alternative treatment of such materials. Considering the aforementioned statements, in this study, we propose a combined use of alkaline and biological pretreatment of rice straw followed by the subsequent anaerobic co-digestion with pig manure for the production of methane. $1.5 \mathrm{M} \mathrm{NaOH}$ was used for alkaline pretreatment which improved the delignification of the rice straw by removing $45.5 \%$ of the lignin content. Aspergillus niger BCRC31130 was employed for the biological pretreatment. Alkaline pretreatment followed by five days of biological pretreatment and subsequent thermophilic co-digestion resulted in the highest amount of methane and reducing sugars production $1834.20 \mathrm{~mL}$ and $2.23 \mathrm{~g} / \mathrm{L}$ respectively. Methane production of the proposed process was 3.17 times higher than that obtained from the untreated rice straw. These results suggested that the enhancement of biodegradation of the rice straw through the combined use of alkaline and biological pretreatment led to higher production of reducing sugars which were converted to methane during co-digestion.
\end{abstract}

Keywords: Rice straw; Methane; Anaerobic co-digestion; Alkaline pretreatment

Abbreviations: TS: Total Solids; VS: Volatile Solids; RS: Rice Straw; [U]: Rice straw untreated; [A]: Rice straw pretreated with $1.5 \mathrm{M} \mathrm{NaOH}$; [A+B5]: Rice straw pretreated with $1.5 \mathrm{M} \mathrm{NaOH}$ followed by biological pretreatment for 5 days; [A+B10]: Rice straw pretreated with $1.5 \mathrm{M}$ $\mathrm{NaOH}$ followed by biological pretreatment for 10 days; [A+B15]: Rice straw pretreated with $1.5 \mathrm{M} \mathrm{NaOH}$ followed by biological pretreatment for 15 days; [B5]: Rice straw undergoing biological pretreatment for 5 days; [B10]: Rice straw undergoing biological pretreatment for 10 days; VFAs: Volatile Fatty Acids

\section{Introduction}

Anaerobic digestion is extensively used technology for the waste utilization and production of biogas. Anaerobic digestion has recently come to light as a potentially significant process for the generation of methane due to its economic and environmental benefits [1]. In fact, numerous studies have been focused for making this technology feasible [2,3]. Rice straw is one of the cheap, renewable and abundantly available lignocellulosic biomass [4]. Lignocellulosic biomass is rich in cellulose, hemicellulose and lignin [5]. Cellulosic components of the rice straw can be hydrolyzed to produce fermentable sugars [6]. However, agricultural waste like rice straw cannot be digested on its own and therefore, require extra methane producing bacteria for the production of methane [7]. Co-digestion of the rice straw with pig manure can assist to get rid of this problem. Co-digestion with the animal manure improves the $\mathrm{C} / \mathrm{N}$ balance, buffering capacity, decreases the risk of ammonia inhibition and further increase the biogas yield and volumetric biogas production rate [8-10]. Moreover, such method of waste management may improve methane yield and enhance the efficiency of the equipment system with the processing of different wastes in a single system [11]. Co-digestion is considered as a more practical approach for large-scale systems as it can be easily implemented by simply adding the inoculum to the existing leachate recirculation system and without the need of any additional infrastructure, chemicals or energy inputs required. It is also reported that the anaerobic co-digestion of rice straw with animal manure and other waste has been recently found efficient in both lab and pilot scale experiments [12]. However, recalcitrant nature of lignin content in the rice straw has been creating obstacles for the desired saccharification of the rice straw by the microorganisms [13]. At the same time, rapid accumulation of volatile fatty acids leads to $\mathrm{pH}$ drop and causes the inhibition of the methanogens [4].

Different methods of pretreatment viz., physical, chemical, biological, physicochemical pretreatment methods is seen in practice to overcome the problems caused by lignin complex. The main aim of these pretreatment methods is to break the lignin seal and reduce the crystallinity of cellulosic component for improved biodegradation [1417]. Alkaline pretreatment by $\mathrm{NaOH}$ causes the swelling of biomass thereby increasing the surface area, reducing the crystallinity and disrupting the linkages between lignin and the cellulosic components $[18,19]$. The concentration of alkali during pretreatment significantly affects the overall methane production. Higher concentration of alkali causes rapid accumulation of volatile fatty acids which inhibits the cellulosic activity of the methanogens while lower concentration may prolong the time of degradation [7,20-22]. Extensive literature studies showed $1.5 \mathrm{M} \mathrm{NaOH}$ is optimum for the alkaline pretreatment of rice straw and agrees with our experimental data [23]. Biological pretreatment by Aspergillus niger on the other hand involves different enzymes produced by the fungi that cause the degradation of lignocellulosic material producing digestible reducing sugars. Due to

*Corresponding author: Chin-Hang Shu, Department of Chemical and Materials Engineering, National Central University, Jung-Li 320, Taiwan, Republic of China Tel: +886-3-422-7151; E-mail: chinshu@ncu.edu.tw

Received September 18, 2015; Accepted October 21, 2015; Published October 26, 2015

Citation: Shu CH, Jaiswal R, Shih JS (2015) Improving Biodegradation of Rice Straw Using Alkaline and Aspergillus niger Pretreatment for Methane Production by Anaerobic Co-Digestion. J Bioprocess Biotech 5: 256 doi:10.4172/2155 9821.1000256

Copyright: $\odot 2015 \mathrm{Shu} \mathrm{CH}$, et al. This is an open-access article distributed under the terms of the Creative Commons Attribution License, which permits unrestricted use, distribution, and reproduction in any medium, provided the original author and source are credited. 
slow rate of degradation, biological pretreatment has been suggested to be used in combination with another pretreatment method for biomass with low lignin content materials like rice straw [5].

In this research, for the first time, we have suggested the combination of alkaline and biological pretreatment of the rice straw. It involves the pretreatment of the rice straw first by $1.5 \mathrm{M} \mathrm{NaOH}$ followed by the pretreatment with Aspergillus niger BCRC 31130. Combination of both these pretreatment methods is assumed to improve the biodegradation of the lignocellulosic biomass. The pretreated rice straw is then allowed to undergo anaerobic co-digestion with pig manure for production of methane gas. Also production of methane gas has been compared for pretreated and untreated rice straw undergoing anaerobic co-digestion.

Operating conditions including temperature, $\mathrm{pH}$, Solids Retention Time (SRT) remarkably influence anaerobic digestion process parameters such as stability and product formation [24]. Methanogenesis, the terminal step of methane formation is temperature dependent [25]. Anaerobic digestion is usually operated at mesophilic temperature $\left(30-40^{\circ} \mathrm{C}\right)$. However, anaerobic digestion offers numerous advantages in thermophilic operation $\left(50-60^{\circ} \mathrm{C}\right)$ such as an increase of reaction rates, an increase of efficiency (fraction of organic solids destroyed), an improvement of solid-liquid separation and an increase of the elimination of pathogenic organisms [26-28]. Therefore, in this study, we have operated anaerobic co-digestion at thermophilic temperature strictly considering the imbalance between higher accumulation of VFA accumulation and inhibition of methanogens.

\section{Materials and Methods}

\section{Management of substrates and inoculum}

The rice straw used in the study was acquired from Taoyuan County, Taiwan. The rice straw was cut into small pieces and chopped by Grinding mill (DM-6, Yu Chi Machinery Co., Taiwan). The particles having size about $2.0 \mathrm{~mm}$ were air dried to remove the moisture content. Then the rice straw was stored in plastic bags at room temperature to prevent any possible hydrolysis.

Fresh pig manure was obtained from a pig farm in Taiwan (Pingzhen, Taoyuan) and was stored at $4^{\circ} \mathrm{C}$. The pig manure and rice straw contained $29.38 \% \mathrm{w} / \mathrm{w}$; $91.3 \% \mathrm{w} / \mathrm{w}$ total solids (TS), $23.24 \% \mathrm{w} / \mathrm{w}$; $79.15 \% \mathrm{w} / \mathrm{w}$ Volatile Solids (VS), respectively. The activated sludge used as the inoculum for anaerobic digestion was obtained from a labscale anaerobic digester.

Aspergillus niger BCRC 31130 used in the present study was purchased from Bioresource Collection and Research Center (BCRC, Taiwan).

\section{Alkaline pretreatment of rice straw with $\mathrm{NaOH}$}

The rice straw was treated by distilled water and $1.5 \mathrm{M} \mathrm{NaOH}$ in a flask. The ratio of solid to liquid was at 1:10 based on available literature $[29,30]$. The prepared flask was maintained at temperature $\left(30 \pm 1^{\circ} \mathrm{C}\right)$ for five days. The pretreated rice straw was rinsed with distilled water and then dried in the oven (Ten-72, Tender) at $60^{\circ} \mathrm{C}$ for $24 \mathrm{~h}$.

\section{Biological pretreatment and combined pretreatment (alkaline followed by biological) of rice straw}

First, $10 \mathrm{~g}$ untreated rice straw was put into a $250 \mathrm{ml}$ shaking flask. $100 \mathrm{~mL}$ of liquid medium was then added into the flask. The liquid medium contained Sodium Carboxymethyl Cellulose $2 \mathrm{~g} / \mathrm{L}$, Peptone $2 \mathrm{~g} / \mathrm{L}, \mathrm{KH}_{2} \mathrm{PO}_{4} 2 \mathrm{~g} / \mathrm{L}, \mathrm{MgSO}_{4} .7 \mathrm{H}_{2} \mathrm{O} 0.3 \mathrm{~g} / \mathrm{L}$, and $\left(\mathrm{NH}_{4}\right)_{2} \mathrm{SO}_{4} 1.4 \mathrm{~g} / \mathrm{L}$, respectively. The flask was then autoclaved for $20 \mathrm{~min}$ at $121^{\circ} \mathrm{C}$ and allowed for cooling to room temperature. It was then inoculated with A. niger BCRC 31130 strain aseptically. The prepared flask was placed in the shakers at temperature $30^{\circ} \mathrm{C}$ and a shaking speed of $120 \mathrm{rpm}$. Biological pretreatment was done for 5-15 days depending on the required conditions.

Searching an optimum biological pretreatment to combined pretreatments was done by subjecting alkali treated rice straw to undergo biological pretreatment for 5, 10 and 15 days as mentioned above.

\section{Anaerobic co-digestion experiment}

The digester used in this study was $1 \mathrm{~L}$ serum glass bottle to which $5 \mathrm{~g}$ pretreated rice straw for 5 days and $60 \mathrm{~g}$ of pig manure was added. It was then seeded with $100 \mathrm{~mL}$ of anaerobic sludge and tap water added to make a working volume of $600 \mathrm{~mL}$. The same procedure was repeated for digesters with pretreated rice straw for 10 and 15 days as well as for untreated rice straw and alkaline pretreated rice straw. The initial $\mathrm{pH}$ of the mixed liquor in each digester was adjusted to $7.5 \pm 0.1$ by using $1 \mathrm{M} \mathrm{HCl}$ or $1 \mathrm{M} \mathrm{NaOH}$. Finally, the digesters were flushed with nitrogen to create anaerobic condition and the digesters were placed in an orbital shaker at $55^{\circ} \mathrm{C}$ for 25 days. The methane content and the methane volume produced from each digester were measured once daily.

\section{Analytical methods}

Total Solids (TS) and total Volatile Solids (VS) for the rice straw and pig manure were determined using standard techniques [31]. The daily methane production for each anaerobic digester was recorded using the water displacement method and the corresponding cumulative methane volume was calculated. Methane was analyzed using a gas chromatograph equipped with a Thermal Conductivity Detector (TCD). The temperatures of the oven, injector port, and TCD were 70,200 , and $200^{\circ} \mathrm{C}$, respectively. Nitrogen was used as carrier gas. The content of cellulose, hemicellulose, and lignin was analyzed according to the standard method of Van Soest [32]. Liquid analyses of rice straw, including $\mathrm{pH}$ and the Volatile Fatty Acids (VFAs) were conducted after the $\mathrm{NaOH}$ pretreatment and biological pretreatment. The concentrations of VFAs, including acetate, propionate and butyrate in the substrate liquid were determined with a gas chromatograph equipped with a Flame Ionization Detector (FID) and capillary column (VF-1ms, $30 \mathrm{~m} \times 0.25 \mu \mathrm{m} \times 0.25 \mathrm{~mm}$ ). The liquid samples were first centrifuged at $6,000 \mathrm{rpm}$ for $5 \mathrm{~min}$ and filtered through a $0.22 \mu \mathrm{m}$ membrane, and finally measured for free acids. The operating temperatures of the injector, detector and oven were 200, 220 and $130^{\circ} \mathrm{C}$ respectively. Nitrogen was again the carrier gas. The enzymatic system was analyzed according to the method of Ghose [33] and Sohail et al. [34].

\section{Results and Discussion}

\section{Comparison of methane production from different source of pretreated rice straw}

Untreated and pretreated rice straw was subjected to thermophilic co-digestion for methane production in different fermenters. Figure $1 \mathrm{a}$ and $1 \mathrm{~b}$ clearly demonstrate the daily methane production and cumulative methane production respectively of the untreated, alkaline and combined pretreated rice straw $[\mathrm{A}+\mathrm{B} 10]$. The cumulative methane production was $577.81 \mathrm{~mL}$ and $862.46 \mathrm{~mL}$ for [U] and [A] respectively. The cumulative methane production of combined pretreated rice 
(a)

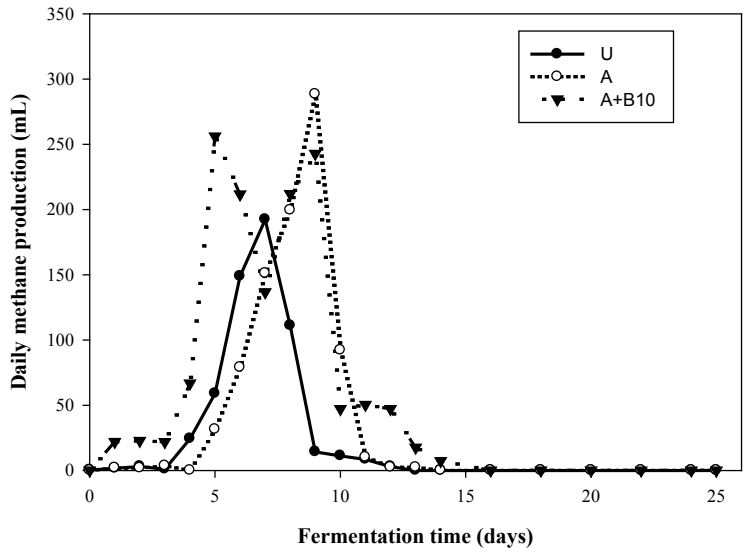

(b)

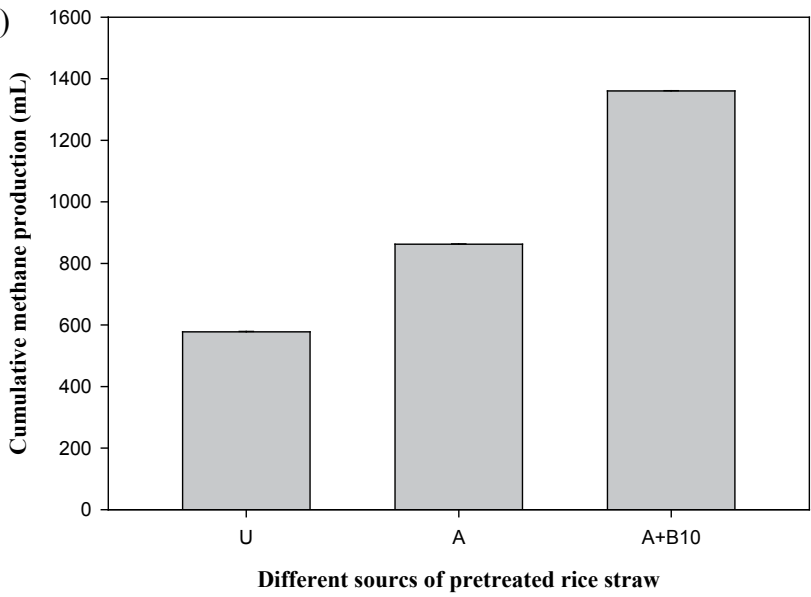

Figure 1: (a) Daily methane production of untreated [U], alkaline $[A]$ and combined pretreated $[A+B 10]$ rice straw (b), Cumulative methane production of untreated $[\mathrm{U}]$, alkaline $[\mathrm{A}]$ and combined pretreated $[\mathrm{A}+\mathrm{B} 10]$ rice straw; $[\mathrm{U}]$ is untreated rice straw; $[A]$ is rice straw pretreated with $1.5 \mathrm{M} \mathrm{NaOH} ;[A+B 10]$ is rice straw pretreated with $1.5 \mathrm{M} \mathrm{NaOH}$ followed by biological pretreatment for 10 days.

straw [A+B10] was $1360.44 \mathrm{~mL}$ after anaerobic co-digestion. From the above results, methane production rate for [U], $[\mathrm{A}]$ and $[\mathrm{A}+\mathrm{B} 10]$ was calculated as 41.27, 61.9 and $85.02 \mathrm{mg} / \mathrm{L} /$ day. As shown in Figure $1 \mathrm{a}$, there were two peaks of the maximum daily methane production observed in combined pretreated rice straw $[\mathrm{A}+\mathrm{B} 10]$ at $5^{\text {th }}$ day and $9^{\text {th }}$ day, but only one peak of maximum daily methane production was untreated $[\mathrm{U}]$ and alkaline $[\mathrm{A}]$ pretreated rice straw, which are in $7^{\text {th }}$ day and $9^{\text {th }}$ day, respectively. However, the maximum daily methane production peak of alkaline $[\mathrm{A}]$ pretreated rice straw was observed at $9^{\text {th }}$ day, which was even longer than that of untreated [U] rice straw.

Results have shown that combined pretreated rice straw samples yielded higher daily methane production over shorter period of time as compared with the untreated rice straw and alkali pretreated rice straw. The biomethanation process mainly constitutes four different phases including hydrolysis, acidogenesis, acetogenesis and methanogenesis [1]. Enhanced enzymatic activity, efficient hydrolysis and increased fermentable sugars during hydrolysis should be responsible for the occurrence of two peaks of daily methane accumulation for the combined pretreated rice straw while only one late peak for the untreated and only alkaline pretreated rice straw. The erratic behavior of the peaks is attributed by the slow growth of methanogens and inhibitory effect of $\mathrm{pH}$ drop on methanogens during acidogenesis.
However, conversion of volatile fatty acids to methane caused the peak recovery by the $9^{\text {th }}$ day during anaerobic co-digestion of combined pretreated rice straw. Also, the higher methane production rate for the combined pretreatment is responsible for higher methane production for $[\mathrm{A}+\mathrm{B} 10]$ than $[\mathrm{U}]$ and $[\mathrm{A}]$. Moreover, higher accumulation of methane shows the competency of thermophilic temperature for the anaerobic co-digestion.

\section{Optimization of combined pretreatment with different biological pretreatment period on methane production}

Furthermore, the optimization of the pretreatment time for the combined pretreatment was targeted. Interestingly, it was found that $[A+B 5]$ produced higher quantity of methane than those of $[A+B 10]$ and $[\mathrm{A}+\mathrm{B} 15]$ as shown in Figure $2 \mathrm{a}$ and $2 \mathrm{~b}$ with the highest production of methane on $5^{\text {th }}$ day of co-digestion. The cumulative methane production was $1834.20 \mathrm{~mL}, 1360.44 \mathrm{~mL}$, and $1301.84 \mathrm{~mL}$ for [A+B5], $[\mathrm{A}+\mathrm{B} 10]$ and $[\mathrm{A}+\mathrm{B} 15]$ respectively after anaerobic co-digestion. These results were $317 \%, 235 \%$, and $225 \%$ respectively higher than [U]. The methane production rate for $[\mathrm{A}+\mathrm{B} 5],[\mathrm{A}+\mathrm{B} 10]$ and $[\mathrm{A}+\mathrm{B} 15]$ were found to be $83.07,85.02$ and $92.98 \mathrm{mg} / \mathrm{L} /$ day respectively.
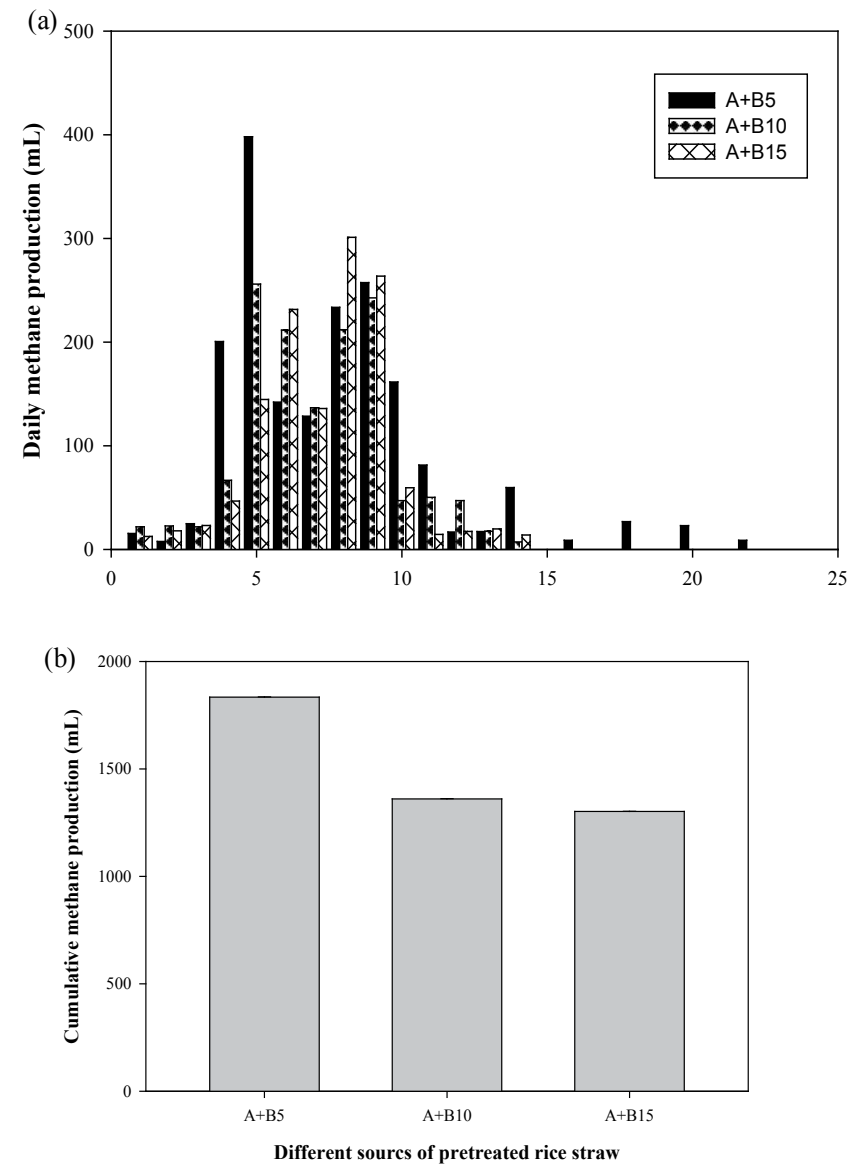

Figure 2: Optimization of combined pretreatment on rice straw with different biological periods. (a), Daily methane production of combined pretreated rice straw for three different periods [A+B5], [A+B10], and [A+B15] (b), Cumulative methane production of combined pretreated rice straw for three different pretreatment period $[A+B 5],[A+B 10]$, and $[A+B 15] ;[A+B 5]$ is rice straw pretreated with $1.5 \mathrm{M} \mathrm{NaOH}$ followed by biological pretreatment for 5 days; $[A+B 10]$ is rice straw pretreated with $1.5 \mathrm{M} \mathrm{NaOH}$ followed by biological pretreatment for 10 days; $[A+B 15]$ is rice straw pretreated with $1.5 \mathrm{M} \mathrm{NaOH}$ followed by biological pretreatment for 15 days. 
Two peaks of maximum daily methane production of each combined pretreatment were observed as shown in Figure 2a and are consistent with the observation in Figure 1a. This might be explained by a higher temperature $\left(55^{\circ} \mathrm{C}\right)$ adopted in this research leads the anaerobic co-digestion to provide optimum growth temperature for methanogens and to facilitate enzymatic hydrolysis on rice straws during co-digestion. The first peak of maximum daily methane production of $[\mathrm{A}+\mathrm{B} 5]$ and $[\mathrm{A}+\mathrm{B} 10]$ occurred at $5^{\text {th }}$ day of co-digestion, and the second peak occurred at $9^{\text {th }}$ day of co-digestion. However, the first peak of maximum daily methane production of [A+B15] occurred at $6^{\text {th }}$ day of co-digestion, and its second peak occurred at $8^{\text {th }}$ day of co-digestion.

From the above mentioned results, it was found that the combined pretreatment $[\mathrm{A}+\mathrm{B} 5]$ of rice straw i.e., alkaline pretreatment $(1.5 \mathrm{M}$ $\mathrm{NaOH}$ ) followed by 5 days of biological pretreatment is best suited for higher methane production. Higher enzyme activity for $[A+B 5]$ should have caused enhanced production of reducing sugar. Due to availability of abundant reducing sugars, there is higher methanogenic activity causing higher yield of methanogens for [A+B5]. Although higher methane production rate was observed for $[A+B 15]$, methane formation could only continue for 14 days thereby decreasing the total volumetric methane production. However, for [A+B5], methane formation takes place for 22 days much higher than the other two conditions and responsible for overall highest cumulative methane production. It suggests that the duration of exposure of the alkali pretreated rice straw for the biological pretreatment longer than 5 days doesn't enhance the methane production by anaerobic co-digestion. Also, it draws our attention for shorter time interval of biological pretreatment for alkali pretreated rice straw resulting higher methane production which sounds economically beneficial.

During methanogenesis, there is rapid accumulation of volatile fatty acids in the acidogenic phase, which may cause drop in $\mathrm{pH}$ and inhibition of methanogens for the synthesis of methane. Therefore, initially, the $\mathrm{pH}$ of digester is adjusted to $7.5 \pm 0.1$ to check the drastic fall in $\mathrm{pH}$. According to Chandra et al. [1], the methane forming bacteria commences the consumption of volatile fatty acids and alkalinity is produced due to production of methane and carbon dioxide thereby rising and stabilizing the $\mathrm{pH}$ of the system favorable for the microorganisms. Higher production of methane from the rice straw undergoing combined pretreatments than those from untreated or only alkaline pretreated rice straw further justifies the improvement of the biodegradation resulted by the combined pretreatment.

\section{Volatile fatty acids and $\mathrm{pH}$ profile of biological and combined pretreatment of rice straw}

The extent of biodegradation of rice straw during different pretreatments could be indirectly observed from the quantity of volatile fatty acids produced during anaerobic co-digestion. The profile of volatile fatty acids during different pretreatments $([B]$ and $[A+B])$ is presented in Figure 3a. The key intermediate products are the short chain fatty acids also known as volatile fatty acids. These fatty acids are indicators of process stability, overload or inhibition. During the initial days; also known as the adaptation period, there was minimal accumulation of volatile fatty acids for both the pretreatment methods. However, the accumulation of VFAs for $[\mathrm{A}+\mathrm{B}]$ was higher than $[\mathrm{B}]$. The accumulation of fatty acids for $[A+B]$ was significantly influenced by the duration of biological pretreatment. Also, the highest accumulation of volatile fatty acids was about $1796.26 \mathrm{mg} / \mathrm{L}$ for the combined pretreatment while $1025.05 \mathrm{mg} / \mathrm{L}$ for only biologically treated sample on $9^{\text {th }}$ day of pretreatment. Acetic acid production was obtained as the major component of the total VFAs compared to propionic acid and butyric acid. Higher acetic acid content indicates that the process is more stable as acetate is more likely converted to $\mathrm{H}_{2} / \mathrm{CO}_{2}$ and finally to methane. The contents of acetic, propionic and butyric acids for the combined pretreatment sample on $9^{\text {th }}$ day were $1567.27 \mathrm{mg} / \mathrm{L}, 192.17$ $\mathrm{mg} / \mathrm{L}$ and $36.79 \mathrm{mg} / \mathrm{L}$ respectively. The accumulation of volatile fatty acids was also characterized by fall in $\mathrm{pH}$. While [B] showed a steady fall in $\mathrm{pH},[\mathrm{A}+\mathrm{B}]$ had gradual decrease in $\mathrm{pH}$ as shown in Figure $2 \mathrm{~b}$. The fall in $\mathrm{pH}$ for biological pretreatment tended to gain stability from the $5^{\text {th }}$ day around $\mathrm{pH}$ 6.5. However, combined pretreatment sample continued $\mathrm{pH}$ drop constantly reaching acidic $\mathrm{pH} 3.3$ on $15^{\text {th }}$ day of pretreatment. Sharp drop in $\mathrm{pH}$ for $[\mathrm{A}+\mathrm{B}]$ was also resulted by the presence of higher quantity of VFAs.

Rapid accumulation of VFAs is inhibitory to the methanogens [32]. The results shown in Figure $3 \mathrm{a}$ and $3 \mathrm{~b}$ supports our technique of adjusting $\mathrm{pH} 7.5 \pm 0.1$ by using $1 \mathrm{M} \mathrm{HCl}$ or $1 \mathrm{M} \mathrm{NaOH}$ during the commencement of anaerobic digestion to provide optimum $\mathrm{pH}$ for the methanogens.

\section{Cellulase activity and production of reducing sugars from different sources of pretreated rice straw}

The cellulase system in A. niger BCRC 31130 is a synergistic association of three enzymes viz., exocellulase, endoglucosidase and $\beta$-glucosidase. Figure $4 \mathrm{a}$ and $4 \mathrm{~b}$ depicts the comparison of cellulose activity for the rice straw samples undergoing biological pretreatment $[\mathrm{B}]$ and alkaline followed by biological pretreatment $[\mathrm{A}+\mathrm{B}]$.

As shown in Figure 4a, A. niger during the biological pretreatment produced very low amount of exocellulase and endoglucosidase but produced significant amount of $\beta$-glucosidase. $\beta$-glucosidase amount is found to constantly increase with increasing number of pretreatment days reaching $1.15 \mathrm{IU} / \mathrm{ml}$ on the $15^{\text {th }}$ day of biological pretreatment. Unfortunately, the degradation of cellulose in rice straw relied on the synergistic association of three different enzymes; thus, high quantity of $\beta$-glucosidase alone as observed in [B] without the assistance of endoglucosidase could not degrade rice straw efficiently.

While [B] shows the increased amount of $\beta$-glucosidase production only, $[A+B]$ shows significant production of all the three enzymes responsible for biomass degradation as shown in Figure $4 \mathrm{~b}$. $\beta$-glucosidase amount is higher on $5^{\text {th }}$ day of $[A+B]$ pretreatment reaching $0.32 \mathrm{IU} / \mathrm{mL}$, shows a decrease pattern from $5^{\text {th }}$ day to $7^{\text {th }}$ day and again regains the increasing tendency.

$\beta$-glucosidase along with exocellulase and endoglucosidase are responsible for formation of reducing sugars. Supplementation of $\beta$-glucosidase also removes cellobiose, a strong inhibitor of carboxymethylcellulases. Figure $4 \mathrm{c}$ illustrates the comparison of the accumulation of reducing sugars produced during different pretreatments. $[\mathrm{A}+\mathrm{B}]$ had higher accumulation of reducing sugar than [B]. The highest amount of reducing sugar was recorded for $5^{\text {th }}$ day of $[\mathrm{A}+\mathrm{B}]$ pretreatment i.e., $[\mathrm{A}+\mathrm{B} 5]$ yielded $2.23 \mathrm{~g} / \mathrm{L}$ of reducing sugar which was much higher than other days of both the pretreatment.

$\beta$-glucosidase is chiefly responsible for conversion of the carbohydrate components to reducing sugar. However, the presence of other two enzymes, exocellulase and endoglucosidase also play a vital role in biomass degradation to reducing sugars [35]. The alkaline pretreatment followed by biological pretreatment ensured better enzymatic activity than only biological pretreatment. As a result, higher quantity of reducing sugars was produced by $[A+B]$ pretreatment. Highest amount of reducing sugars was also produced 

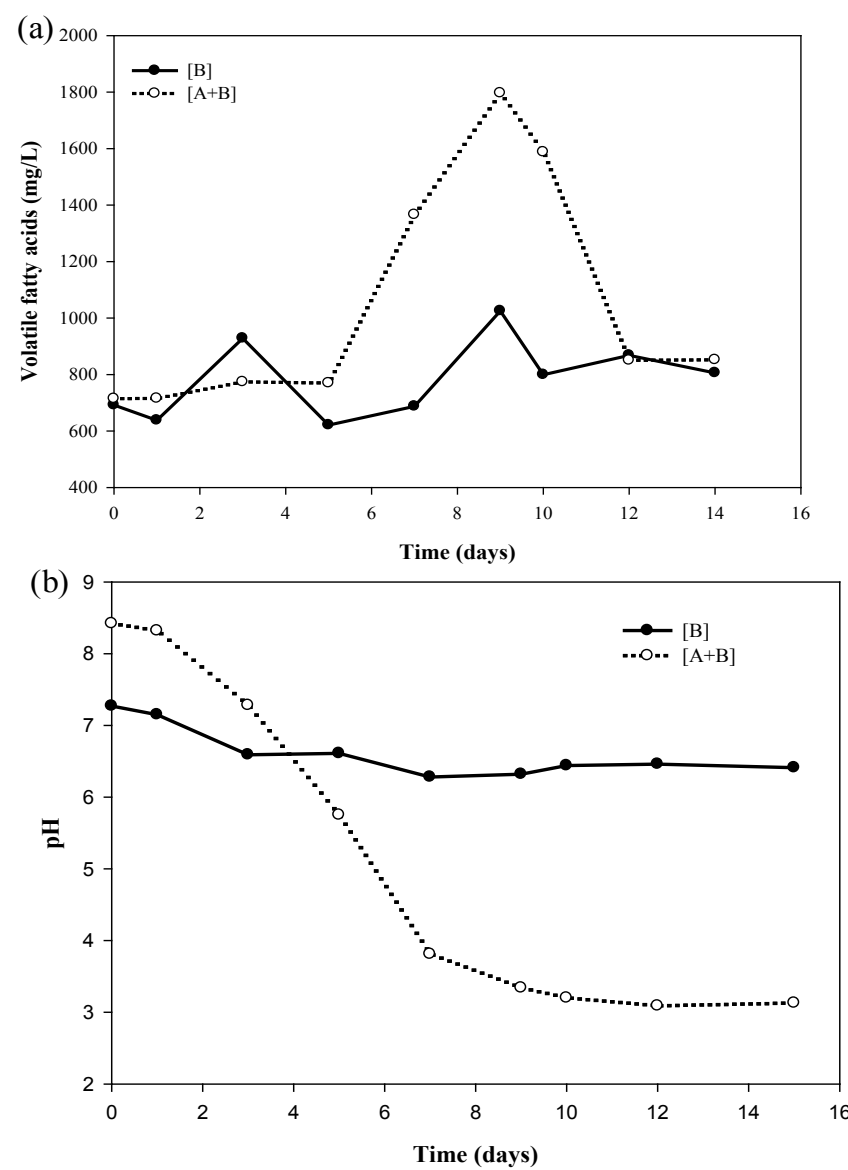

Figure 3: Volatile fatty acids profile (a) and $\mathrm{pH}$ profile (b) during biological pretreatment and combined pretreatment $[A+B]$. $[B]$ is biological pretreatment; $[A+B]$ is alkaline followed by biological pretreatment.

on $5^{\text {th }}$ day of $[A+B]$ pretreatment as seen in Figure $4 \mathrm{c}$ because $[A+B 5]$ had the best proportion of all the three enzymes acting synergistically for breakdown of the biomass. For [A+B5] pretreatment, the breakage of the lignin seal during alkaline pretreatment allowed the exposure of the carbohydrate materials to the enzyme produced by A. niger during biological pretreatment. As a result, higher enzyme activity followed by enhanced sugar production was observed for $[\mathrm{A}+\mathrm{B} 5]$. Untreated rice straw is reluctant to cellulose activity due to the resistance offered by the persistent lignin complex.

\section{Effect of combined pretreatment on compositions of rice straw}

Lignocellulosic biomass can be subjected to bioconversion into fermentable sugars, which can be further utilized for methane and other biofuel production [36]. The main purpose of the pretreatment is the disruption of lignin seal of the biomass for the availability of the digestible sugars. It has been observed that the composition of the rice straw is significantly affected by the combined pretreatment compared to other pretreatment methods. Table 1 illustrates the changes in the main composition of rice straw after $\mathrm{NaOH}$ and biological pretreatment. Pretreatment [A] contained $81.12 \%$ cellulose, $8.23 \%$ hemicellulose, $5.80 \%$ lignin and $0.56 \%$ ashes. Lignin reduction was found to be $45.5 \%$ after subjecting untreated rice straw $[\mathrm{U}]$ to alkaline pretreatment. Pretreatments $[A+B 5]$, and $[A+B 10]$ exhibited significant differences in the composition as shown in Table 1. Contrary to this, pretreatments
[B5] and [B10] exhibited marginal changes in the composition. The compositional contents of hemicelluloses, cellulose, and lignin were degraded from $30.85 \%, 38.2 \%$, and $10.64 \%$ in rice straw to $30.6 \%$, $37.29 \%$, and $10.43 \%$ respectively on 5 days of pretreatment [B5], and to $30.24 \%, 37.53 \%$, and $10.73 \%$ on the 10 days [B10]. During $\mathrm{NaOH}$ and A. niger $\mathrm{BCRC} 31130$ combined pretreatment $[\mathrm{A}+\mathrm{B}]$, the composition of rice straw was changed significantly over time. The compositional contents of hemicelluloses, cellulose, and lignin were degraded from $8.23 \%, 81.12 \%$, and $5.8 \%$ in rice straw to $7.42 \%, 72.86 \%$, and $5.76 \%$
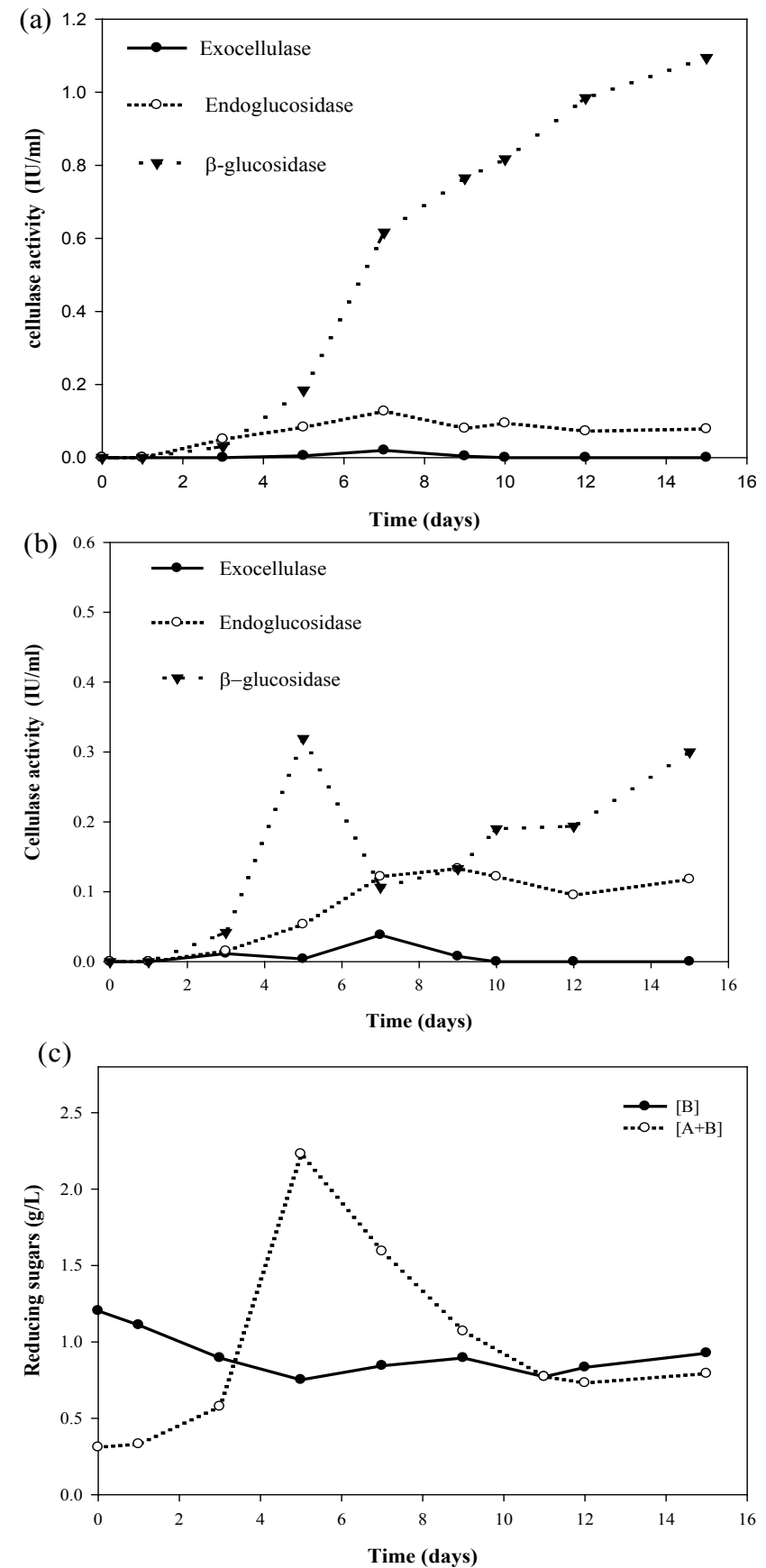

Figure 4: Cellulase activity of biologically pretreated rice straw (a), Cellulase activity of combined pretreated rice straw (b) and Reducing sugar production during biological pretreatment and combined pretreatment $[A+B](c)$. $[B]$ is biological pretreatment; $[A+B]$ is alkaline followed by biological pretreatment. 
Citation: Shu CH, Jaiswal R, Shih JS (2015) Improving Biodegradation of Rice Straw Using Alkaline and Aspergillus niger Pretreatment for Methane Production by Anaerobic Co-Digestion. J Bioprocess Biotech 5: 256 doi:10.4172/2155-9821.1000256

Page 6 of 7

\begin{tabular}{|c|c|c|c|c|}
\hline Conditions & Lignin & Cellulose & Hemicellulose & Ash \\
\hline$[\mathrm{U}]$ & 10.64 & 38.20 & 30.85 & 1.02 \\
\hline$[\mathrm{A}]$ & 5.80 & 81.12 & 8.23 & 0.56 \\
\hline$[\mathrm{A}+\mathrm{B} 5]$ & 5.76 & 72.86 & 7.42 & 0.56 \\
\hline$[\mathrm{A}+\mathrm{B} 10]$ & 5.74 & 60.97 & 6.84 & 0.58 \\
\hline [B5] & 10.43 & 37.29 & 30.60 & 1.16 \\
\hline [B10] & 10.73 & 37.53 & 30.24 & 1.02 \\
\hline
\end{tabular}

Table 1: Changes of main compositions of rice straw after $\mathrm{NaOH}$ and biological pretreatment $\%$. $[\mathrm{U}]$ is untreated rice straw; $[\mathrm{A}]$ is rice straw pretreated with $1.5 \mathrm{M}$ $\mathrm{NaOH} ;[A+B 5]$ is rice straw pretreated with $1.5 \mathrm{M} \mathrm{NaOH}$ followed by biologica pretreatment for 5 days; [A+B10] is rice straw pretreated with $1.5 \mathrm{M} \mathrm{NaOH}$ followed by biological pretreatment for 10 days; [B5] is biological pretreatment for 5 days; [B10] is biological pretreatment for 10 days.

respectively on 5 days of pretreatment $[\mathrm{A}+\mathrm{B} 5]$, and to $6.84 \%, 60.97 \%$, and $5.74 \%$ on 10 days $[\mathrm{A}+\mathrm{B} 10]$.

From the above observation, it is evident that the combination of the alkaline and biological pretreatment ensured better biodegradation of the lignocellulosic biomass. Alkaline pretreatment caused the swelling of the lignocellulosic biomass thereby increasing the internal surface area. As a result, there is reduction in the polymerization and crystallization leading to increased susceptibility of the complex to undergo disruption and separation of the lignin component from cellulose and hemicellulose [18]. At the same time use of $1.5 \mathrm{M} \mathrm{NaOH}$ is also cost effective and produced overwhelming results. Once the lignin seal is broken, the different cellulase enzymes produced by $A$. niger act on the biomass for improved biodegradation. As a result, $[\mathrm{A}+\mathrm{B} 5]$ and $[A+B 10]$ showed better degradation of rice straw with higher lignin reduction and increased cellulose and hemicellulose content. However, there is no much significant difference in compositional changes for $[\mathrm{A}+\mathrm{B} 5]$ and $[\mathrm{A}+\mathrm{B} 10]$ considering the number of days for biological treatment. Therefore, $[\mathrm{A}+\mathrm{B} 5]$ is chosen as the best condition for the pretreatment of rice straw. During uncoupled biological pretreatment with A. niger, [B5] and [B10], reduced compositional changes were observed because the lignin seal might have still persisted blocking the exposure of the cellulosic components to the cellulolytic enzymes from the fungi.

\section{Conclusion}

The results of this study suggested that combination of alkali pretreatment and biological pretreatment for rice straw followed by anaerobic co-digestion with pig manure is a promising approach for production of methane. The combination of the pretreatment allows the lignocellulosic material to accomplish efficient biodegradation thereby enhancing the methane production during anaerobic co-digestion. At the same time, it also shortens the pretreatment time which is an added advantage for the feasibility of the process. Adjusting pH $7.5 \pm 0.1$ by using $1 \mathrm{M} \mathrm{HCl}$ or $1 \mathrm{M} \mathrm{NaOH}$ is necessary for providing optimal range of $\mathrm{pH}$ for methanogens. Similarly, operation of anaerobic co-digestion at thermophilic temperature $\left(55^{\circ} \mathrm{C}\right)$ showed higher conversion of volatile fatty acids to methane gas. Monitoring the rapid accumulation of volatile fatty acids is mandatory for stabilization of the co-digestion process. Future work should be focused on establishing optimized ratio of rice straw and pig manure for co-digestion that can establish a more robust and stable process thermophilic co-digestion is highly dependent upon the composition of influents.

\section{Acknowledgements}

We sincerely acknowledge the financial grant provided by Ministry of Science and Technology of Taiwan (MOST 104-2221-E-008-109) for conducting this research.

\section{References}

1. Chandra R, Takeuchi $H$, Hasegawa $T$ (2012) Methane production from lignocellulosic agricultural crop wastes: A review in context to second generation of biofuel production. Renew Sustainable Energy Rev 16: 1462-1476.

2. Silalertruksa T, Gheewala SH, Sagisaka M, Yamaguchi K (2013) Life cycle GHG analysis of rice straw bio-DME production and application in Thailand. Appl Energy 112: 560-567.

3. Acharya PB, Acharya DK, Modi HA (2008) Optimization for cellulose production by Aspergillus niger using saw dust as substrate. Afr J Biotechnol 7: 41474152.

4. Ye J, Li D, Sun Y, Wang G, Yuan Z, et al. (2013) Improved biogas production from rice straw by co-digestion with kitchen waste and pig manure. Waste Manag 33: 2653-2658.

5. Agbor VB, Cicek N, Sparling R, Berlin A, Levin DB (2011) Biomass pretreatment: fundamentals toward application. Biotechnol Adv 29: 675-685.

6. Chen M, Xia L, Xue P (2007) Enzymatic hydrolysis of corncob and ethanol production from cellulosic hydrosylate. Int Biodeterior Biodegradation 59: 85-89.

7. Gu Y, Chen X, Liu Z, Zhou X, Zhang Y (2014) Effect of inoculum sources on the anaerobic digestion of rice straw. Bioresour Technol 158: 149-155.

8. Comino E, Rosso M, Riggio V (2010) Investigation of increasing organic loading rate in the co-digestion of energy crops and cow manure mix. Bioresour Technol 101: 3013-3019.

9. Alvarez R, Lidén G (2008) Anaerobic co-digestion of aquatic flora and quinoa with manures from Bolivian Altiplano. Waste Manag 28: 1933-1940.

10. Lehtomäki A, Huttunen S, Rintala JA (2007) Laboratory investigations on codigestion of energy crops and crop residues with cow manure for methane production: Effect of crop to manure ratio. Resource, Conservation and Recycling 51: 591-609.

11. Jiménez J, Guardia-Puebla Y, Cisneros-Ortiz ME, Morgan-Sagastume JM, Guerra G, et al. (2015) Optimization of the specific methanogenic activity during the anaerobic co-digestion of pig manure and rice straw, using industrial clay residues as inorganic additive. Chem Eng J 259: 703-714.

12. Mussoline W, Esposito G, Lens P, Spagni A, Giordano A (2013) Enhanced methane production from rice straw co-digested with anaerobic sludge from pulp and paper mill treatment process. Bioresour Technol 148: 135-143.

13. Chen F, Dixon RA (2007) Lignin modification improves fermentable sugar yields for biofuel production. Nat Biotechnol 25: 759-761.

14. Chen X, Zhang Y, Gu Y, Liu Z, Shen Z, et al. (2014) Enhancing methane production from rice straw by extrusion pretreatment. Appl Energy 122: 34-41.

15. Zheng M, Li X, Li L, Yang X, He Y (2009) Enhancing anaerobic biogasification of corn stover through wet state $\mathrm{NaOH}$ pretreatment. Bioresour Technol 100: 5140-5145.

16. Siegert I, Banks C (2005) The effect of volatile fatty acid additions on the anaerobic digestion of cellulose and glucose in batch reactors. Process Biochem 40: 3412-3418.

17. Carlsson M, Lagerkvist A, Morgan-Sagastume F (2012) The effects of substrate pre-treatment on anaerobic digestion systems: a review. Waste Manag 32: 1634-1650.

18. Krishania M, Vijay VK, Chandra R (2013) Methane fermentation and kinetics of wheat straw pretreated substrates co-digested with cattle manure in batch assay. Energy 57: 359-367.

19. Haghighi Mood S, Hossein Golfeshan A, Tabatabaei M, Salehi Jouzani G Najafi GH, et al. (2013) Lignocellulosic biomass to bioethanol, a comprehensive review with a focus on pretreatment. Renew Sustainable Energy Rev 27: 77-93.

20. Chandra R, Takeuchi H, Hasegawa T, Kumar R (2012) Improving biodegradability and biogas production of wheat straw substrates using sodium hydroxide and hydrothermal pretreatments. Energy 43: 273-282.

21. Wang $Y$, Zhang $Y$, Wang J, Meng $L$ (2009) Effects of volatile fatty acid concentrations on methane yield and methanogenic bacteria. Biomass and Bioenergy 33: 848-853.

22. Zhou Z, Meng Q, Yu Z (2011) Effects of methanogenic inhibitors on methane production and abundances of methanogens and cellulolytic bacteria in in vitro ruminal cultures. Appl Environ Microbiol 77: 2634-2639. 
Citation: Shu CH, Jaiswal R, Shih JS (2015) Improving Biodegradation of Rice Straw Using Alkaline and Aspergillus niger Pretreatment for Methane Production by Anaerobic Co-Digestion. J Bioprocess Biotech 5: 256 doi:10.4172/2155-9821.1000256

23. He Y, Pang Y, Liu Y, Li X, Wang K (2008) Physicochemical characterization of rice straw pretreated with sodium hydroxide in the solid state for enhancing biogas production. Energy Fuels 22: 2775-2781.

24. Vanwonterghem I, Jensen PD, Rabaey K, Tyson GW (2015) Temperature and solids retention time control microbial population dynamics and volatile fatty acid production in replicated anaerobic digesters. Sci Rep 5: 8496.

25. Yvon-Durocher G, Allen AP, Bastviken D, Conrad R, Gudasz C, et al. (2014) Methane fluxes show consistent temperature dependence across microbial to ecosystem scales. Nat Lett 507: 488-491.

26. Amani T, Nosrati M, Sreekrishnan TR (2010) Anaerobic digestion from the viewpoint of microbiological, chemical, and operational aspects-a review. Environ Rev 18: 255-278.

27. Labatut RA, Angenent LT, Scott NR (2014) Conventional mesophilic vs. thermophilic anaerobic digestion: a trade-off between performance and stability? Water Res 53: 249-258.

28. Kim M, Ahn YH, Speece RE (2002) Comparative process stability and efficiency of anaerobic digestion; mesophilic vs. thermophilic. Water Res 36: 4369-4385.

29. Mtui GYS (2009) Recent advances in pretreatment of lignocellulosic wastes and production of value added products. Afr J Biotechnol 8: 1398-1415.
30. Krishania M, Bakal SB, Chaurasia SP (2010) Bioethanol production from lignocellulosic materials: pretreatment, saccharification and fermentation. $J$ Biofuels 1: 236-244.

31. Daby D, Turner J, Jago C (2002) Microbial and nutrient pollution of coastal bathing waters in Mauritius. Environ Int 27: 555-566.

32. Van Soest PJ, Robertson JB, Lewis BA (1991) Methods for dietary fiber, neutral detergent fiber, and nonstarch polysaccharides in relation to animal nutrition. $J$ Dairy Sci 74: 3583-3597.

33. Ghose TK (1987) Measurement of cellulase activities. Pure \& Appl Chem 59: 257-268.

34. Sohail M, Naseeb S, Sherwani SK, Sultana S, Aftab S, et al. (2009) Distribution of hydrolytic enzyme among native fungi: Aspergillus the pre-dominant genus of hydrolase producer. Pak J Botany 41: 2567-2582.

35. Li Q, He YC, Xian M, Jun G, Xu X, et al. (2009) Improving enzymatic hydrolysis of wheat straw using ionic liquid 1-ethyl-3-methyl imidazolium diethyl phosphate pretreatment. Bioresour Technol 100: 3570-3575.

36. Mosier N, Wyman C, Dale B, Elander R, Lee YY, et al. (2005) Features of promising technologies for pretreatment of lignocellulosic biomass. Bioresour Technol 96: 673-686. 